\title{
'Evergreen' Peach, Its Inheritance and Dormant Behavior
}

\author{
J. Rodriguez-A. \\ Colegio de Postgraduados, Chapingo, Mexico
}

W.B. Sherman

Fruit Crops Department, University of Florida, Gainesville, FL 32611

\author{
R. Scorza and M. Wisniewski \\ U.S. Department of Agriculture/ARS, Appalachian Fruit Research Station, Box 45, Wiltshire Rd, \\ Kearneysville, WV 25430
}

\author{
W.R. Okie \\ U.S. Department of Agriculture/ARS, Southeastern Fruit and Tree Nut Research Laboratory, P.O. Box \\ 87, Byron, GA 31008
}

Additional index words. dormancy, chilling requirement, cold hardiness

\begin{abstract}
The evergreen (EVG) peach, first described in Mexico, was used as a parent with deciduous (DE) peaches to develop $F_{1}$ and $F_{2}$ hybrid populations in Mexico, Florida, Georgia, and West Virginia. $F_{1}$ trees were DE and $F_{2}$ plants segregated 3 DE : 1 EVG. In West Virginia, the most temperate location, the heterozygous class could be distinguished in the first few years of growth by late leaf abscission in the fall. Segregation ratios suggest that the EVG trait is controlled by a single gene, evg, the EVG state being homozygous recessive. Evergreen trees were characterized by insensitivity of shoot tips to daylength and failure of terminal growth to cease growth until killed by low temperature. Lateral buds of EVG trees went dormant in the fall. Deep supercooling occurred in both EVG and DE trees, but it appeared later in EVG trees, was of shorter duration, and occurred to a lesser extent. Evergreen germplasm may be useful in developing peach cultivars for frost-free subtropic and tropical areas. It also presents a useful system for studying dormancy and cold hardiness.
\end{abstract}

The 'Evergreen' (EVG) is a feral, seed-propagated peach in central Mexico, growing in the area near lat. $18^{\circ} 53^{\prime}$ to $18^{\circ} 11^{\prime} \mathrm{N}$ and long. $98^{\circ} 42^{\prime} \mathrm{W}$. It evidently descended from introductions by Spanish conquerors. This area of production varies from 900 to 2200 meters in elevation, is without killing frosts, has $\approx 85 \%$ of its rain $(1250 \mathrm{~mm})$ from early June to mid-October, and is without supplemental irrigation. Flowers and fruits on EVG trees occur year-round with one main crop ripening in November to early December and a second, lesser crop in June (Acosta and Barrios, 1987; Diaz, 1974). (The second crop is usually not harvested due to small fruit induced by drought and low demand due to competition of other fruiting species.) Summer bloom sets fruit because night temperatures at this elevation are not above 15C (Edwards, 1987; Edwards et al., 1990). Fruit require about 160 days to mature from full bloom. Thus, flowering in summer (July) gives a crop in winter and flowering in winter (January) gives a crop in summer (Diaz, 1974; Sanchez, 1975).

The insensitivity of the EVG peach to cessation of terminal growth under shortening photoperiods and lower temperatures (Mowrey and Sherman, 1986) and the ability to set flower buds throughout the year make it an interesting genotype. The availability of closely related deciduous (DE) and EVG germplasm may provide an interesting model system to study processes related to acclimation and dormancy where the two processes are not superimposed on each other. Our observations revealed that indicators of the onset of dormancy, such as leaf senescence and abscission, and adherence of bark tissue to the underlying xylem tissue did not

Received for publication 13 Mar. 1992. Accepted for publication 28 Oct. 1993. Florida Agricultural Experiment Station Journal Series No. R-02172. The authors acknowledge the excellent technical assistance of Glenn Davis and Lenard Gilreath during this study. The cost of publishing this paper was defrayed in part by the payment of page charges. Under postal regulations, this paper therefore must be hereby marked advertisement solely to indicate this fact. develop in EVG trees except in climates where they were partially or fully defoliated by stress or leaf diseases. The objective of this study was to test the hypothesis (Lammerts, 1945) that expression of the EVG habit is under control of a single recessive gene and to develop comparative information on the ability of EVG trees to acclimate in different locations.

\section{Materials and Methods}

Trees of EVG peach were propagated onto locally used rootstocks at Chapingo, Mexico, Gainesville, Fla., Byron, Ga., and Kearneysville, W.Va. Observations were made for more than 2 years on their growth and fruiting at Tetela (Mexico), Chapingo, Gainesville, Byron, and Kearneysville. The EVG peach was hybridized with 'Maravilha', BRI, BR6, 'Capo Bosco', 'Coral', L72-4-20, 'Majestic', 'Rutgers Red Leaf', and 'Empress' DE peaches at four locations (Table 1). The nine seed parent genotypes ranged from 250 to 1000 chill units (cu). Chilling requirement (CR) of parents, $\mathrm{F}_{1}$, and $\mathrm{F}_{2}$ seedlings was recorded by comparing bloom and leafing dates of these seedlings with standard "key" cultivars, as shown by Sherman et al. (1988). The sources of the pollen parent EVG peach in Florida and Mexico were seedlings of the 'Tetela EVG'. The source of EVG in Georgia and West Virginia was PI442380, which was collected in 1979 as seed from a local market in Tupachula, Chiapas, Mexico (lat. $15^{\circ} \mathrm{N}$, long. $92^{\circ}$ $\mathrm{W})$. The vendor reported that the fruit were grown in Mexico State. The four seedlings and their progenies grown at Byron had white flesh fruit with little exterior red color and ripened in August. These characteristics fit the descriptions of the EVG trees grown at Gainesville and Chapingo. At Kearneysville, open-pollinated (OP) seed were collected from an $\mathrm{F}_{1}$ tree of 'Empress' (dwarf) OP $\times$ EVG (PI442380). It is assumed that most OP seed resulted from selfing (Fogle, 1977). Since the $F_{1}$ planting consisted of several 
Table 1. Progeny characteristics of nine deciduous $\left(\mathrm{DE}^{\mathrm{z}}\right)$ seed parents crossed with evergreen $\left(\mathrm{EVG}^{\mathrm{y}}\right)$. Homogeneity $\mathrm{X}^{2}=2.02$; $P=0.95$ based on 3:1 segregation.

\begin{tabular}{|c|c|c|c|c|c|c|c|}
\hline Location & Seed parent & $\mathrm{cu}$ & $\begin{array}{l}\mathrm{F}_{1} \\
\text { obs. }^{2}\end{array}$ & $\begin{array}{l}\text { Estimated } \mathrm{F}_{1} \\
\mathrm{cu}\end{array}$ & & $\begin{array}{l}\mathrm{F}_{2} \\
\text { exp. }\end{array}$ & $\begin{array}{c}\text { Estimated } \\
\mathrm{F}_{2} \text { lateral } \\
\text { bud cu range }\end{array}$ \\
\hline \multirow[t]{2}{*}{ Florida } & Maravilha & 250 & DE 26 & 350 & 81 & 77 & $150-400$ \\
\hline & & & EVG 0 & & 22 & 26 & $150-450$ \\
\hline \multirow[t]{10}{*}{ Mexico } & Maravilha & 250 & DE 13 & 350 & 42 & 42 & $150-400$ \\
\hline & & & EVG 0 & & 14 & 14 & $150-300$ \\
\hline & BR1 & 350 & DE 24 & 400 & 83 & 82 & $250-500$ \\
\hline & & & EVG 0 & & 26 & 27 & $250-450$ \\
\hline & BR6 & 350 & $\mathrm{DE} \quad 3$ & 400 & 20 & 19 & $150-450$ \\
\hline & & & EVG 0 & & 6 & 7 & $150-350$ \\
\hline & Capo Bosco & 400 & DE 15 & 400 & 25 & 26 & $150-450$ \\
\hline & & & EVG 0 & & 9 & 8 & $150-450$ \\
\hline & Coral & 350 & DE 14 & 400 & 66 & 61 & $300-500$ \\
\hline & & & EVG 0 & & 15 & 20 & $250-450$ \\
\hline \multirow[t]{4}{*}{ Georgia } & Majestic & 800 & DE 43 & 750 & 196 & 196 & $450-650$ \\
\hline & & & EVG 0 & & 66 & 66 & \\
\hline & L72-4-20 & 800 & $\mathrm{DE}$ & 650 & 92 & 92 & $550-650$ \\
\hline & & & EVG 0 & & 31 & 31 & \\
\hline \multirow[t]{2}{*}{ Rutgers } & Redleaf & 1000 & $\mathrm{DE}$ & 650 & 11 & 11 & (unavailable) \\
\hline & & & EVG 0 & & 4 & 4 & \\
\hline \multirow[t]{2}{*}{ West Virginia } & Empress & $?$ & $\mathrm{DE}$ & (unavailable) & & & \\
\hline & & & EVG 0 & & 34 & 34 & \\
\hline
\end{tabular}

${ }^{\mathrm{z}} \mathrm{DE}=$ Terminal buds set and growth ceased.

$\mathrm{EVG}=$ Terminal buds continued growing until winter killed.

rows of closely spaced trees, any seeds derived from outcrossing were likely to be the result of intercrossing between $\mathrm{F}_{1}$ trees. $\mathrm{F}_{2}$ seeds were germinated in the greenhouse in Winter 1986 and fieldplanted in June 1987. Dwarf and standard trees were segregated, but planted in adjacent rows. At all locations growth type was evaluated visually. Trees were classified as EVG if they maintained their leaves and terminal buds growing at the end of the fall, started terminal bud growth earlier in spring than lateral buds, or both.

Deep supercooling capacity (as low temperature exotherms) of xylem tissues and flower buds was determined at Byron on a monthly basis from Sept. 1989 through Jan. 1990 and at Kearneysville from Oct. through Dec. 1989. Freezing of deep supercooled water was characterized in three to five buds and 0.5 $\mathrm{g}$ of xylem segments from EVG and DE trees using differential thermal analysis as described by Ashworth (1984). A cold-hardiness screening of EVG and DE floral buds was conducted in Dec. 1989. Approximately 45 to 60 buds were evaluated at each 5C temperature interval from -5 to $-30 \mathrm{C}$. Death of primordia expressed as browning was assessed following an overnight thaw at $3 \mathrm{C}$ and $24 \mathrm{~h}$ at 25C (Ashworth, 1984).

At Chapingo, cold damage was evaluated in $\mathrm{F}_{2}$ (open-pollinated) populations after a natural freeze $(-8 \mathrm{C})$ on 24 Dec. Cold damage was rated on a 0 to 5 scale, where $0=$ no tree damage and $5=$ severe tree damage to the tree.

\section{Results}

The EVG peach is indigenous to the area around Tetela, where it was observed to have terminal buds that continue to grow whenever temperatures are high enough. This growth habit results in long shoots and a weeping-type tree. In Tetela, the lowest CR ( $<250$ estimated $\mathrm{cu}$ ) peach genotypes from the Florida breeding program set terminal buds in winter and enter endodormancy, producing spring flowers that set a crop. Flower bud formation in EVG peach occurs continuously along the shoot as it matures. Flower bud differentiation is concentrated in two main periods as this peach is forced into short ecodormancy periods by drought and low temperatures in summer and winter, respectively. Lateral, mature leaves are lost before the July flowering, mainly due to drought but also to powdery mildew [Sphaerotheca pannosa (Wallr. ex Fr.) Lev.]. Similarly, leaves are lost before January flowering due mainly to powdery mildew and rust [Transchelia pruni-spinosa (Pers.) Diet] species, but also due to drought. Following leaf loss, a new flush of shoot growth is produced in some lateral buds. Each main bloom and crop are produced by flower buds that developed on new growth made during the preceding fruit development period. Peaches of low chilling requirement from Florida, grown in the same conditions near Tetela, do not have these two main flowering periods and their terminals and lateral buds enter into endodormancy during the winter months.

At Gainesville and Chapingo ( $\approx 400 \mathrm{cu})$, seedlings of EVG (seed imported from Tetela) grow as in the Tetela region, except that winter temperatures below-7C kill new fully expanded leaves and terminate growth. Lateral flower and leaf buds of EVG at Gainesville enter into endodormancy. Spring bloom and leafing indicate that these buds require 450 to $500 \mathrm{cu}$ to initiate growth without exhibiting symptoms of inadequate winter chilling. At Byron, the mature EVG (PI 442380) leaves drop off due to drought and rust in the fall or are killed by freezing temperatures. Terminal growth continues intermittently throughout the winter, although the tips of the EVG in Byron may be killed. In the absence of such damage, winter growth continues. Mature trees at Byron survived record lows of -16C in 1983 and -21C in 1988, with damage only to the terminal growth. This pattern of winter growth does not appear to make the trunk particularly cold-tender, under the conditions at Byron, despite some lack of acclimatization. Bloom occurs over an extended period from early February through 
March, corresponding to genotypes with CRs of 450 to $700 \mathrm{cu}$. The extended bloom may be related to differences in bud maturity along the twig.

Lateral buds of EVG trees (PI442380) planted at Kearneysville appear to enter dormancy as fall progresses. Terminal growth continues until killed by low temperatures $(-2 \mathrm{C})$. Leaf drop does not occur until late in December. It is not clear if leaf drop is the result of cold temperatures, wind, or both.

$\mathrm{F}_{1}$ hybrids of $\mathrm{EVG} \times \mathrm{DE}$ peaches exhibited a normal type of growth in all four locations of this study. However, leaf drop occurred later in the fall at Byron and Kearneysville than at Gainesville and Chapingo in most of the $F_{1}$ seedlings, probably more as a result of a lower CR than the effects of the EVG gene. The $\mathrm{CR}$ of the $\mathrm{F}_{1}$ progeny ranged from 350 to $850 \mathrm{cu}$, about the midparent mean (Table 1). The $\mathrm{CR}$ of the lateral buds in the $\mathrm{F}_{2}$ progenies ranged from 150 to $650 \mathrm{cu}$, except for the 'Empress' cross in which no data were taken. These $F_{1}$ and $F_{2}$ (openpollinated) data indicate that the $\mathrm{CR}$ of the $\mathrm{EVG}$ peach is probably between 400 and $500 \mathrm{cu}$. When terminals of shoots were not killed by freezing, but instead growth was halted by low temperatures, terminal growth of the EVG started notably earlier than lateral budbreak. This behavior permitted an easy screening of the EVG seedlings at the beginning of the growing season. There was no apparent influence of the EVG continuous terminal growth habit on the $\mathrm{CR}$ of the lateral buds in the $\mathrm{F}_{1}$ and $\mathrm{F}_{2}$ seedlings. All of the $\mathrm{F}_{2}$ seedling progenies in Table 1 fit the $3 \mathrm{DE}: 1$ EVG ratio, indicating that this trait is controlled by a single recessive gene with little environmental influence and is independent of the CR of lateral flower and leaf buds.

At Byron, $\mathrm{F}_{2}$ seedlings segregated at a $3 \mathrm{DE}: 1 \mathrm{EVG}$ ratio (Table 1). However, recovery of yellow-fleshed EVG trees was less (59 white : 7 yellow) than the expected $3: 1\left(\mathrm{X}^{2}=6.68, P<0.01\right)$. The deciduous progeny approximated 3:1 (144 white : 52 yellow).

$\mathrm{F}_{2}$ trees were observed for EVG in 1988 and 1989 at Kearneysville. In Dec. 1988, three classes of trees were readily observable in both the standard size and dwarf trees. Class I (DE) consisted of trees in which lateral and terminal buds were apparently dormant and all leaves had fallen from the trees at the time of normal leaf drop for DE trees in the area. Both lateral and terminal buds of Class II (semi-EVG) trees appeared dormant but most leaves were green and firmly attached to twigs at the time of evaluation in December, at least 1 month after normal leaf drop. Terminal shoots of Class III (EVG) trees continued growth, but lateral buds appeared dormant. Leaves were green and firmly attached. These trees segregated as Class I, 34 trees; Class II, 68 trees; and Class III, 34 trees, an exact 1:2:1 ratio. Chi squares for a 1:2:1 ratio (Class I, II, III) in standard and dwarf trees were .037 and .054 , respectively $(P=.95)$, indicating no association of the EVG gene with either growth habit. In Dec. 1989, trees were again evaluated, but only Classes I and III could be distinguished in a ratio of 102:34 (Table 1).

DE seedlings at Chapingo suffered less cold damage after a natural freeze than seedlings with the EVG habit (Table 2). Evergreen seedlings probably suffered the most damage because they had more prolonged growth in the fall and the tissues did not acclimate before the first killing freeze. Leaf drop was later in the fall for DE trees than for standard low-chill requirement cultivars, but lateral and terminal growth did not continue into the winter.

In late December the EVG trees exhibited LTEs in the range of -7 to $-11 \mathrm{C}$, whereas LTEs in the DE trees were in the range of 7 to $-22 \mathrm{C}$. In the freezing test, $11 \%$ of EVG buds survived $-11 \mathrm{C}$ compared with $80 \%$ of DE at the same temperature (Fig. 1). In general, floral buds from the DE trees responded similarly to other
Table 2. Cold-damage evaluation in three $F_{2}$ seedling populations of deciduous (DE) and evergreen (EVG) habit during a natural freeze $(-8 C)$ on 24 Dec. 1990 at Chapingo, Mexico.

\begin{tabular}{|c|c|c|c|c|c|c|}
\hline \multirow{2}{*}{$\begin{array}{l}\mathrm{CR}^{\mathrm{z}} \\
\text { (cu) }\end{array}$} & \multicolumn{2}{|c|}{$\mathrm{BRI} \times \mathrm{EVG}$} & \multicolumn{2}{|c|}{ Capo Bosco $\times$ EVG } & \multicolumn{2}{|c|}{ Coral $\times \mathrm{EVG}$} \\
\hline & $\mathrm{DE}$ & EVG & $\mathrm{DE}$ & EVG & $\mathrm{DE}$ & $\overline{E V G}$ \\
\hline 150 & --- & --- & 1.7 & --- & --- & $\overline{---}$ \\
\hline 250 & $0.7^{y}$ & 2.4 & 1.2 & 1.5 & 2.0 & 2.3 \\
\hline 350 & 0.3 & 1.3 & 0.6 & 0.7 & 1.0 & 2.3 \\
\hline 450 & 0.5 & 1.4 & 1.1 & -- & 0.7 & 3.2 \\
\hline
\end{tabular}

${ }^{\overline{\mathrm{z}}} \mathrm{CR}=$ chilling requirement $(\mathrm{cu})$ classes in $\mathrm{F}_{2}$ lateral buds.

${ }^{{ }} 0=$ No damage; $5=$ severe damage.

Table 3. Progressive change in the extent of low-temperature exotherm of current year shoots of deciduous (DE) and evergreen (EVG) germplasm. Low-temperature exotherm midpoint temperatures were determined using differential thermal analysis.

\begin{tabular}{lcc}
\hline & DE & EVG \\
\cline { 2 - 3 } Date & \multicolumn{2}{c}{ Midpoint (C) } \\
\hline Byron, Ga. & & \\
29 Sept. 1989 & -18 & -17 \\
12 Oct. 1989 & -17 & -15 \\
13 Nov. 1989 & -18 & -15 \\
13 Dec. 1989 & -24 & -24 \\
4 Jan. 1990 & -30 & -21 \\
Kearneysville, W.V. & & \\
18 Sept. 1989 & -20 & -16 \\
25 Sept. 1989 & -21 & -16 \\
11 Oct. 1989 & -23 & -16 \\
30 Oct. 1989 & -27 & -16 \\
9 Nov. 1989 & -27 & -18 \\
3 Dec. 1989 & -31 & -25 \\
\hline
\end{tabular}

peach floral buds (Quamme, 1974).

Deep supercooling in DE flower buds began to appear in midOctober and the low temperature exotherm (LTE) appeared at increasingly lower temperatures as acclimation increased. In contrast, deep supercooling in the EVG trees did not appear until late November. Sporadic flowering in the EVG trees began in Georgia during the first week of January.

The LTE of xylem tissues in current year shoots in DE and EVG trees from September through January at Kearneysville and Byron (Table 3 ) followed trends similar to previous reports (Wisniewski and Ashworth, 1986). The ability to deep supercool increased over the fall period in both DE and EVG, but the extent of deep supercooling was much greater in the DE. A detailed study of cold acclimation and polypeptide changes in current year shoots of DE and EVG genotypes has been reported by Arora et al. (1992). Further evaluation of samples from Kearneysville after 3 Dec. 1989 are not included due to severe cold temperatures that resulted in dieback of the EVG trees to ground level. Evaluation of samples from Byron were discontinued after the onset of flowering in the first week of January. A significant level of deep supercooling was still present in the xylem tissues of EVG samples at the time of flowering.

\section{Discussion}

"Evergreen" growth was studied by Lammerts (1945) on two $\mathrm{F}_{2}$ populations (16 and 70 trees) of 'Chinese Dwarf Evergreen' $\times$ 'Rio Oso Gem'. These populations segregated 5 DE : 6 semi-EVG : 5 


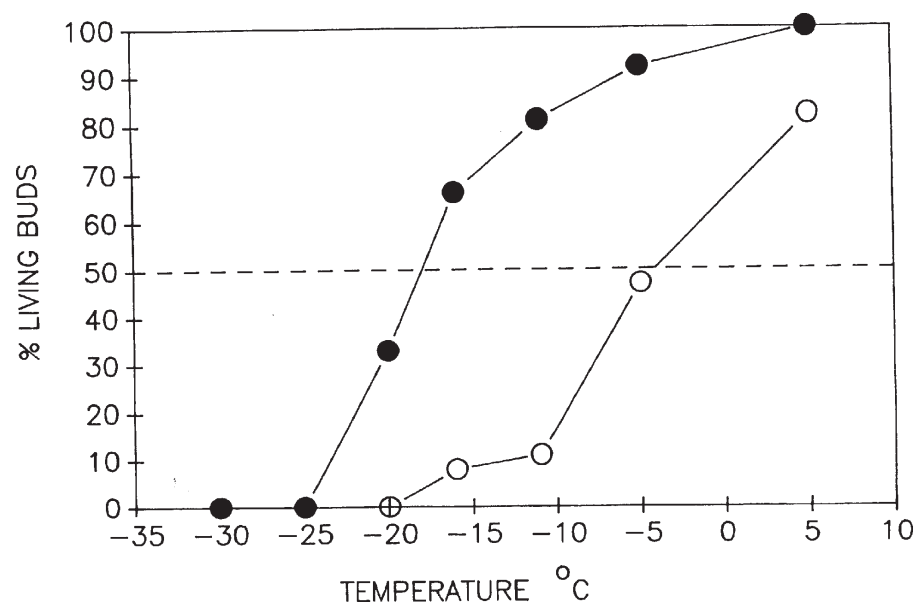

Fig. 1. Percent survival of floral buds from deciduous $(-$ and evergreen germplasm (O) collected on 29 Dec. 1989 in Byron, Ga.

EVG and 59 DE : 10 semi-DE : 1 EVG trees. Lammerts suggested that the EVG character is recessive but a product of several factors inhibited in their expression by low temperature. He also found that the evergreen trait was not as strongly expressed in older trees. His lack of clear segregation ratios may have resulted from modifying genetic factors and climatic differences.

Our results in subtropical and temperate climates, based on larger populations than Lammerts (1945) and different sources of EVG and DE germplasm, indicate that the EVG habit is controlled by a single gene and that the expression of the heterozygote $\mathrm{DE} /$ EVG, but not the homozygous EVG, is affected by both cold temperatures and tree age. We propose the symbol evg for the EVG gene.

The EVG gene maintains the tree in a more active form during fall, retarding acclimation of the tissues and rendering them more susceptible to winter damage. We hypothesize that this situation may be a lack of phytochrome response in this genotype. The terminal buds of the EVG plants usually respond faster to conditions that favor growth, probably because the plant never sets a terminal bud due to a constant activity of the apical meristem. The quick response of this plant to terminate ecodormancy in lateral buds in the Tetela area explains why it is possible to produce two main crops in a subtropical climate without any physiological manipulation of the tree. The segregation obtained in $F_{1}$ and $F_{2}$ populations indicates that effectively this peach has a $C R$ of $\approx 450$ $\mathrm{cu}$ as opposed to previous beliefs that it had no CR. The gene that confers the EVG character may be of special interest in the breeding of peaches in the frost-free subtropics and tropical highlands. This peach is interesting germplasm for acclimation response studies due to its lack of response to shortening day lengths in terminal growth cessation and terminal bud dormancy.

In field tests at Byron, unbudded EVG (PI442380) seedlings are surviving well on a peach tree short-life site. We don't know if this superior survival relates to root reaction to ring nematode or to a unique trunk physiology that makes the tree less prone to spring cold damage.

\section{Literature Cited}

Acosta, F.G. and E.P. Barrios. 1987. Effecto del raleo de flor y de fruto sobre el dessarrollo de la fruta en el durazno (Prunus persica L. Batsch) "Siempreverde". Agrociencia 68:83-92.

Arora, R., M. Wisniewski, and R. Scorza. 1992. Cold acclimation in genetically related (sibling) deciduous and evergreen peach [Prunus persica (L.) Batsch]. Plant Physiol. 99:1562-1568.

Ashworth, E.N. 1984. Xylem development in Prunus flower buds and the relationship to deep supercooling. Plant Physiol. 74:862-865.

Diaz, M.D. 1974. Vegetative and reproductive growth habits of evergreen peach trees in Mexico. Proc. XIX Intl. Hort. Congr. 18:525.

Edwards, G.R. 1987. Temperature in relation to peach culture in the tropics. Acta Hort. 199:61-62.

Edwards, G.R., E.R. Sinclair, and K.R. Chapman. 1990. Computer assisted selection of locations in south-east Asia for the continuous cropping of apples and peaches. Acta Hort. 279:61-66.

Fogle, H.W. 1977. Self-pollination and its implication in peach improvement. Fruit Var. J. 31:74-75.

Lammerts, W.E. 1945. The breeding of ornamental edible peaches for mild climates. I. Inheritance of tree and flower characters. Ann. J. Bot. 32:53-60.

Mowrey, B.D. and W.B. Sherman. 1986. Relationship between autumn growth cessation and chilling requirement in peach. Fruit Var. J. 40:2428.

Quamme, H.A. 1974. An exothermic process involved in freezing injury to flower buds of several Prunus species. J. Amer. Soc. Hort. Sci. 99:315-317.

Sanchez, G.F. 1975. Estudio preliminar del durazno (Prunus persica L. Batsch) Siempreverde (de guia) en el Noreste del Edo. de Moreles. Tesis de Licenciatura. Chapingo, Mexico.

Sherman, W.B., P.M. Lyrene, N.F. Childers, F.G. Gmitter, and P.C. Andersen. 1988. Low-chill peach and nectarine cultivars for trial in Florida. Proc. Fla. State Hort. Soc. 101:241-244.

Wisniewski, M. and E.N. Ashworth. 1986. Seasonal variation in deep supercooling and dehydrative resistance. HortScience 21:503-505. 